\title{
IMPLEMENTASI PENGGUNAAN MEDIA BONEKA JARI UNTUK MENGEMBANGAN KEMAMPUAN INTERPERSONAL SISWA SDN 027 SAMARINDA ULU
}

\author{
Ratna Khairunnisa $^{1}$, Selvi Oye ${ }^{2}$ \\ (Universitas Widya Gama Mahakam Samarinda) \\ e-mail: ${ }^{1}$ ratna@uwgm.ac.id
}

\begin{abstract}
Abstrak
Penelitian ini dilaksanakan di SDN 027 Samarinda Ulu pada siswa kelas II C. Media pembelajaran dengan menggunakan boneka jari dipilih agar siswa tidak hanya belajar secara aspek kognitif saja, namun juga dapat mengembangkan kemampuan interpersonal yang dimiliki dengan bantuan boneka jari tersebut. Kemampuan interpersonal merupakan salah satu kunci agar siswa dapat membentuk kerjasama dan saling menghargai antar temantemannya, dimulai dari ruang lingkup terkecil terlebih dahulu yaitu teman-teman yang berada dikelasnya. Dengan menggunakan boneka jari, maka siswa akan belajar untuk saling berkomunikasi satu sama lain, sehingga kesenjangan yang ada diantara mereka pun diharapkan akan berubah menjadi keakraban.
\end{abstract}

Kata kunci: Boneka jari, Kemampuan Interpersonal

\begin{abstract}
This study was conducted at SDN 027 Samarinda Ulu in grade II students C. Media learning by using a finger puppet is chosen so that students not only learn in cognitive aspects only, but can also develop interpersonal skills that are owned with the help of the finger puppets. Interpersonal skills are one of the keys so that students can form cooperation and mutual respect among their friends, starting from the smallest scope in advance of the friends who are in the class. By using finger Puppet, students will learn to communicate with each other, so that the gaps that exist among them are expected to be turned into familiarity.
\end{abstract}

Keywords: Finger puppet, Interpersonal skills

\section{Pendahuluan}

Anak-anak dan bermain merupakan suatu kesatuan yang sukar untuk dipisahkan, meskipun anak tersebut sudah duduk di bangku Sekolah Dasar. Pada jenjang kelas rendah yaitu kelas 1, 2 dan 3 SD kegiatan belajar mengajar hendaknya dapat dikemas melalui permainan yang melibatkan siswa didalam aktivitas tersebut, agar siswa mengetahui bahwa belajar bukan hal yang membosankan namun belajar adalah kegiatan yang menyenangkan. Sehingga ketika mendengar kata belajar, anak merasa bahwa yang dilakukannya bukanlah sebuah beban, tetapi belajar adalah salah satu kegiatan yang sama seperti kegiatan rutin lainnya seperti makan, minum, tidur dan bermain.

Dalam melakukan segala aktivitasnya, tentu anak tidak terlepas dari adanya partner atau teman yang menemani hari-harinya. Kemampuan seorang anak untuk dapat membaur dengan teman-teman di lingkungannya disebut kemampuan interpersonal. Kemampuan interpersonal merupakan suatu kemampuan yang tidak dimiliki oleh semua orang, namun kemampuan ini dapat diasah, terutama pada usia anak-anak, agar anak terbiasa untuk dapat menyesuaikan diri pada suatu lingkungan tertentu dan 
menanamkan nilai-nilai kerjasama serta menghargai orang lain. Dari hasil pengamatan pra penelitian, peneliti menemukan bahwa siswa-siswi di kelas II C SDN 027 Samarinda Ulu masih ada terjadi kesenjangan dalam arti, siswa-siswi masih belum terlihat membaur dengan teman sejawatnya yang lain, cenderung terlihat berkelompok-kelompok dan masih malu-malu untuk bergabung dengan teman yang lain diluar dari kelompok sepermainannya.

SDN 027 Samarinda Ulu telah menerapkan Kurikulum 2013 yang artinya pembelajaran tidak hanya sebatas aspek pengetahuan namun juga menanamkan pendidikan karakter pada siswa-siswinya. Sesuai dengan hakikat dari Kurikulum 2013 bahwa kurikulum 2013 lebih ditekankan pada pendidikan karakter, terutama pada tingkat dasar, yang akan menjadi pondasi bagi tingkat berikutnya, melalui pengembangan kurikulum 2013 yang berbasis karakter dan kompetensi (Mulyasa,2013). Agar siswa merasa tidak canggung dan segan untuk membaur, maka peneliti menggunakan media boneka jari untuk mengajak para siswa saling menyapa temannya dengan menggunakan berbagai tokoh yang ada pada boneka jari tersebut dan membuat sebuah cerita sederhana sesuai tema pelajaran yang sedang berjalan, inilah yang menjadi dasar peneliti mencoba mengimplementasikan penggunakan media boneka jari untuk menciptakan suasana belajar yang menyenangkan. Dari latar belakang yang telah dijabarkan diatas, maka peneliti tertarik untuk melakukan penelitian dengan judul Implementasi Penggunaan Media Boneka Jari Untuk Mengembangkan Kemampuan Interpersonal Siswa SDN 027 Samarinda Ulu.

\section{Metode Penelitian}

Penelitian ini menggunakan metode penelitian kualitatif, yaitu suatu prosedur penelitian yang menghasilkan data deskriptif berupa ucapan atau tulisan dan perilaku yang dapat diamati dari subyek yang diteliti (Moleong, 2014:157). Pendekatan ini diarahkan pada latar dan individu secara holistik atau utuh, sehingga dalam penelitian ini tidak boleh mengisolasikan individu atau organisasi ke dalam variabel atau hipotesis, akan tetapi perlu memandangnya sebagai bagian dari suatu keutuhan.

\subsection{Waktu dan tempat penelitian}

Penelitian ini dilaksanakan pada tanggal 4 Oktober 2019 sampai 12 Desember 2019 dengan menggunakan ruang kelas II C SDN 027 Samarinda sebagai tempat penelitian. Peneliti memilih melalukan penelitian pada kelas II C karena anak-anak dikelas ini merupakan siswa yang baru mengenal dunia Sekolah Dasar selama kurang lebih 1 tahun dan setiap kenaikkan kelas, siswa selalu di rolling, sehingga mereka memerlukan waktu lagi untuk mengenal teman-teman barunya. Kelas II C cenderung tergolong kelas anak-anak yang pemalu dan kurang luwes dalam membina hubungan dengan temanteman barunya, untuk itulah peneliti tertarik menggunakan kelas II C sebagai tempat untuk melakukan penelitian.

\subsection{Teknik Pengumpulan Data}

\subsubsection{Pengamatan (Observasi)}

Observasi yaitu teknik pengumpulan data dengan melakukan pengamatan langsung pada objek yang diteliti di lapangan sesuai dengan keadaan atau fenomena yang terjadi pada saat penelitian berlangsung.

\subsubsection{Wawancara (Interview)}

Wawancara atau interview merupakan teknik pengumpulan data dengan memberikan pertanyaan secara lisan guna memperoleh informasi sesuai dengan penelitian yang dikaji.

\subsubsection{Dokumentasi}

Dokumentasi merupakan data tertulis tentang berbagai hal seperti catatan, surat, foto, dan lainlain terkait penelitian yang dilakukan. 


\subsubsection{Teknik Analisis Data}

Penelitian ini menggunakan teknik analisis data deskiptif-kualitatif, yaitu mendeskripsikan data yang diperoleh yang diperkuat dengan hasil wawancara.

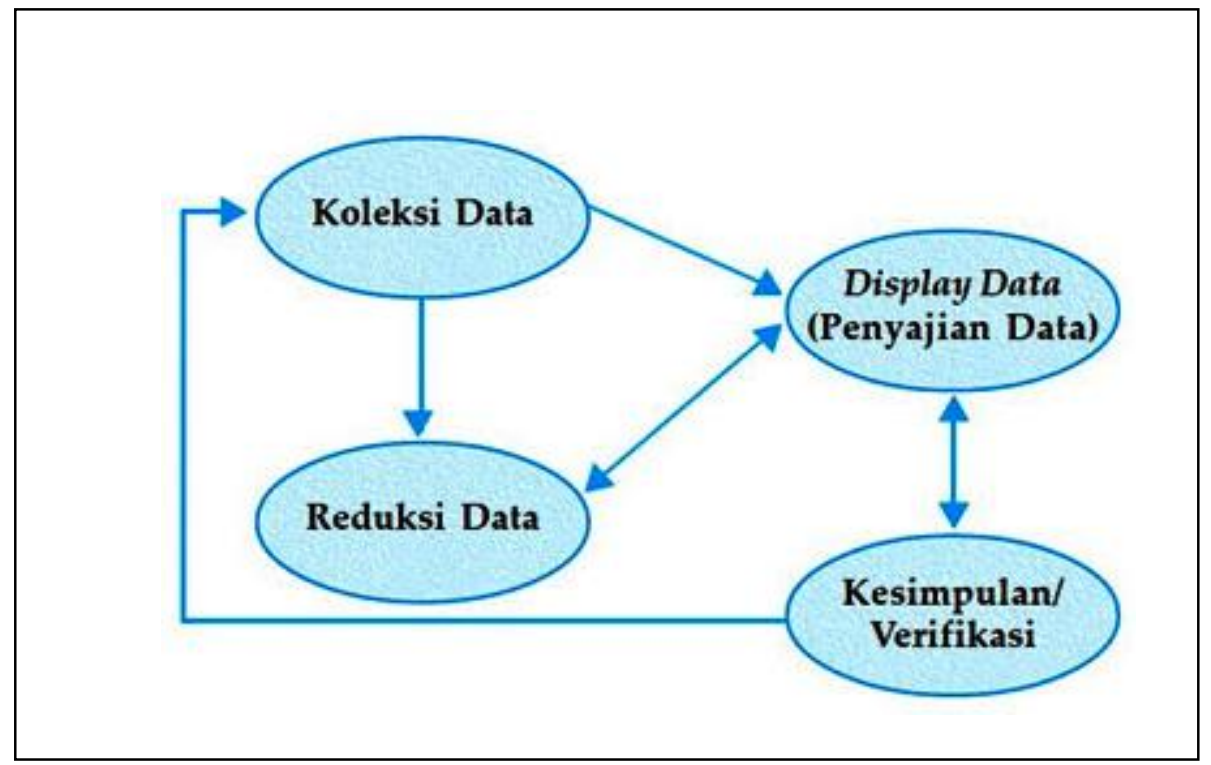

1. Pengumpulan data

Pengumpulan data yaitu mengumpulkan data di lokasi penelitian dengan melakukan observasi, wawancara dan dokumentasi dengan menentukan strategi pengumpulan data yang dipandang tepat dan untuk menentukan fokus serta pendalaman data pada proses pengumpulan data berikutnya.

2. Reduksi data

Reduksi data merupakan suatu bentuk analisis yang menajamkan, menggolongkan, mengarahkan, membuang yang tidak perlu dan mengorganisasikan data sedemikian rupa sehingga diperoleh kesimpulan akhir dan di verifikasi.

3. Penyajian data

Penyajian data adalah kegiatan mengelompokkan data yang telah direduksi. Pengelompokkan data dilakukan dengan menggunakan label atau lainnya.

4. Penarikan kesimpulan (verifikasi).

Penarikan kesimpulan adalah kegiatan analisis yang lebih dikhususkan pada penafsiran data yang telah disajikan.

\section{Hasil dan Pembahasan}

Boneka jari merupakan media yang peneliti pilih untuk membuat anak menjadi atraktif dan berani berinteraksi dengan temannya tanpa harus menunggu untuk disapa lebih dahulu dengan temannya. Media boneka jari yang dibuat menggunakan kertas bekas dan telah dicetak dengan berbagai pola tokoh cerita sehingga akan melatih siswa untuk dapat menggunakan media tersebut sesuai dengan imajinasi mereka. Dengan menggunakan boneka jari dilapangan berdasarkan hasil observasi maka terlihat kemampuan anak seperti berikut :

\section{a. Kemampuan anak untuk berfantasi}

Ketika penerapan penggunaan media boneka jari dilakukan terlihat 10 orang siswa sangat baik dalam membuat cerita dengan menggunakan berbagai tokoh yang telah disediakan, 13 orang siswa masuk kategori baik dalam bergotong royong dikelompoknya saat menggunakan media tersebut, 2 orang siswa cukup baik dan 2 orang siswa termasuk dalam kategori kurang, karena siswa terlihat canggung dan bingung untuk berkhayal atau berfantasi sesuai tokoh yang ada. Dari hasil wawancara lapangan dengan guru kelas, 2 orang siswa yang termasuk kategori kurang merupakan siswa yang tergolong dalam anak berkebutuhan khusus (ABK) karena 
sekolah ini merupakan sekolah inklusi, walaupun demikian peneliti pun berusaha semaksimal mungkin untuk menggali potensi siswa yang kurang tersebut.

b. Kemampuan bersosialisasi

Kemampuan bersosialisasi ketika siswa menggunakan boneka jari sangat terlihat bahwa siswa mampu menggunakan boneka jari tersebut dengan sangat baik, hasil pengamatan dilapangan bahwa ada 16 orang siswa sangat baik dalam bersosialisasi dengan menggunakan media tersebut, 9 orang siswa dengan kategori baik dan 2 orang siswa dengan kategori cukup baik. Wawancara yang dilakukan terhadap siswa menunjukkan mereka ada rasa malu-malu untuk memulai percakapan dengan teman yang tidak terlalu akrab, sehingga ada rasa canggung dalam memainkan perannya sesuai dengan cerita yang telah disepakati oleh kelompoknya. Tidak ada perbedaan ketika saaat proses pembelajaran antara anak ABK dan anak-anak lainnya didalam kelas.

c. Aspek Bahasa

Pada hasil observasi dilapangan bahwa dengan menggunakan media boneka jari terlihat 18 orang siswa memiliki penyampaian dan kosa kata Bahasa yang sangat baik, 5 orang siswa memiliki kemampuan berbahasa yang baik, dan 4 oranag siswa memiliki kemampuan berbahasa cukup. Kemampuan berbahasa dan berkomunikasi memegang peranan yang sangat besar dalam penggunaan media boneka jari, dari sini nampak jelas terlihat kemampuan siswa dari aspek berbahasa.

\section{d. Keterampilan dan kreativitas}

Hasil observasi lapangan menunjukkan terdapat 10 orang siswa dengan keterampilan dan kreativitas yang sangat baik, 14 orang siswa dengan kategori baik, dan 3 orang siswa dengan kategori cukup baik dalam keterampilan dan kreativitas.

Kemampuan Interpersonal Siswa

a. Kemampuan berhubungan dengan orang lain/bekerjasama

Berdasarkan hasil observasi lapangan yang dilakukan dilapangan dengan indikator kemampuan berhubungan dengan orang lain atau bekerjasama pada awal pelaksanaan penelitian dari 27 siswa, ada 5 orang siswa yang memiliki kemampuan bekerjasama dengan sangat baik, 15 siswa dengan kategori memiliki kemampuan bekerjasama yang baik, 3 orang siswa dengan kategori cukup baik, serta 4 orang siswa termasuk ke dalam kategori kurang. Dari hasil wawancara dengan guru kelas menunjukkan bahwa siswa masih merasa malu-malu jika ingin membantu temannya karena merasa belum dekat dan akrab, terutama siswa perempuan, mereka enggan jika terlalu dekat dengan siswa laki-laki.

b. Berteman dan memiliki banyak teman

Dari kegiatan dilapangan yang dilakukan, nampak 13 siswa sangat baik dalam berteman dan memiliki banyak teman dikelas hal ini nampak dari tidak segannya mereka untuk melakukan kontak dengan teman dikelompok lain meskipun tidak berada dalam satu kelompok, 8 siswa masuk ke dalam kategori baik terlihat dari adanya kontak atau komunikasi dalam kegiatan seperti meminjam peralatan dengan teman dikelompok lain, serta ada 2 orang siswa masuk dalam kategori cukup, dan 4 orang siswa dengan kategori kurang.

c. Menikmati suasana ketika berada ditengah banyak orang

Tidak semua anak merasa nyaman berada ditengah-tengah keramaian, begitupun siswa, nampak terlihat ada 16 siswa yang termasuk kategori sangat baik karena mereka senang dengan situasi ramai dan mereka sangat menikmati keberadaan ditengah keramaian bersama dengan teman-temannya, ada 8 orang siswa yang terlihat baik ketika berada ditengah-tengah keramaian, dan ada 3 orang siswa terlihat kurang menyukai ketika berada ditengah banyak orang, hal ini terlihat dari ekspresi siswa yang merasa kurang nyaman ketika berada pada kondisi ramai, hal tersebut sesuai dengan hasil wawancara yang dilakukan bahwa ada beberapa anak $\mathrm{ABK}$ dikelas ini sehingga beradaptasi dengan lingkungan yang ramai merupakan kebiasaan yang masih harus dilatih dan diasah agar mereka terbiasa berada dilingkungan yang ramai.

\section{d. Menengahi Pertengkaran}


Dalam pelaksanaan kegiatan tentu terdapat konflik atau pertengkaran kecil ditengah-tengah siswa, baik pertengkaran didalam kelompoknya maupun dengan teman yang berbeda kelompok. Dari pengamatan dilapangan ada 14 orang siswa yang terlihat sangat baik menengahi pertengkaran atau konflik yang terjadi dikelas, terlihat 9 orang siswa yang dengan baik dapat menengahi pertengakran atau konflik yang ada di antara teman-temannya, dan ada 4 orang siswa yang kurang dapat menengahi konflik di antara teman-temannya, siswa tersebut terlihat cuek saat ada teman sekelompoknya yang terlibat pertengkaran kecil. Dari pengamatan yang dilakukan, siswa sudah mampu memecahkan konflik maupun pertengkaran yang ada ditengah-tengah mereka.

\subsection{Implemetasi penggunaan boneka jari}

Hasil penelitian dilapangan menunjukkan bahwa dengan menggunakan boneka jari, membuat siswa semakin kreatif dan mengasah keterampilan serta ketelitian mereka hal ini terlihat dari kehatihatian siswa dalam menggunting pola boneka, meenmpelkan maupun memainkan boneka tersebut, selain itu penggunaan media boneka jari mampu membuat suasana semakin akrab tanpa disadari oleh siswa, mereka yang tadinya tidak akrab menjadi dekat, yang awalnya komunikasi sangat kurang dan jarang menjadi intens, dan kosa kata mereka dalam berbahasa pun bertambah seperti yang dikemukakan oleh Kemal (dalam Yosastra, et al. 2013: 3) bahwa permainan boneka jari dapat melatih kemampuan berbahasa, berhitung, dan kecakapan motorik halus.

Selain kosa kata siswa bertambah dari aspek bahasa, kemampuan siswa untuk bersosialisasi dan bekerjasama pun terbina dengan baik, bahkan siswa terlihat tidak canggung dan segan untuk berinteraksi dengan teman-temannya, yang awalnya hubungan mereka tidak akrab menjadi akrab dan bersahabat, hal ini sejalan dengan pendapat Zaman, B., dkk (2005:13) mengemukakan bahwa boneka jari dapat berfungsi untuk mengajak anak bersosialisasi, dan bergotong royong. Dengan adanya media boneka jari maka siswa dapat lebih luwes dalam bergaul dan memiliki banyak teman.

Dari aspek sosialisasi sangat terlihat kedekatan antar siswa, yang tadinya mereka tidak akrab dan kurang bertegur sapa, dengan adanya pembelajaran dengan menggunakan media boneka jari ini, siswa pun menjadi akrab dan suasana pembelajaran terasa hangat. Dari hasil wawancara dengan guru kelas, ada beberapa anak yang memang tergolong anak berkebutuhan khusus (ABK) sehingga dalam kegiatan pembelajaran terkadang mereka kurang mampu untuk fokus mengikuti instruksi sehingga dibutuhkan banyak waktu untuk membimbing mereka, dengan adanya penggunaan media boneka jari sangat terlihat teman-teman dikelasnya juga membantu anak-anak berkebutuhan khusus (ABK) untuk sama-sama terlibat didalam proses pembelajaran tanpa membedakan-bedakan. Hal inilah yang harus dipelihara dan dikembangkan yaitu kepekaan mereka terhadap lingkungan sosialnya. Dengan demikian maka siswa akan dapat bekerjasama tanpa perlu diinstruksikan lagi.
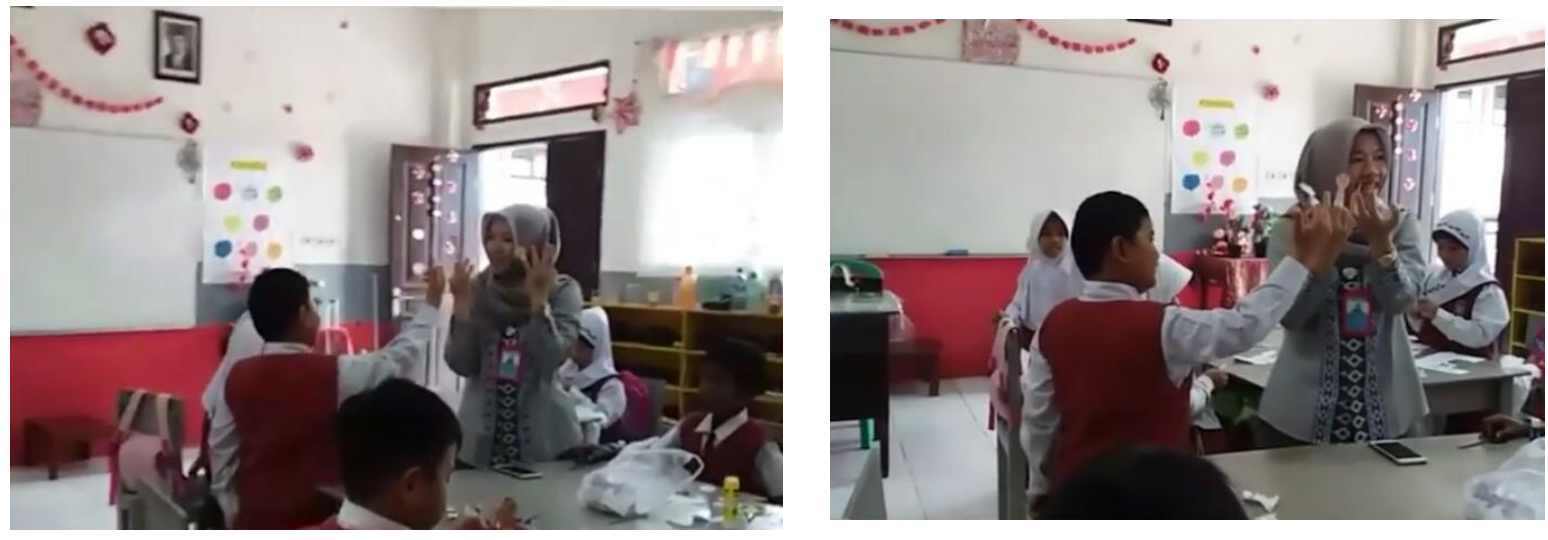

Gambar Implementasi penggunaan boneka jari 


\subsection{Faktor Pendukung dalam pelaksanaan kegiatan pembelajaran}

Faktor pendukung yang ada dilapangan yaitu adanya sifat terbuka dari para siswa untuk dapat menerima pelajaran yang akan disampaikan sehingga proses sosialisasi pun berjalan dengan sangat baik, guru kelas pun sangat piawai membawakan materi pelajaran dengan memanfaatkan boneka jari ini untuk membangun interaksi antara guru dengan siswa, serta antar siswa dengan siswa. Selain itu adanya sikap kooperatif yang ditunjukkan oleh siswa, membuat suasana akrab dan kekeluargaan hadir ditengah-tengah proses pembelajaran. Kondisi diatas sesuai dengan pendapat yang menyatakan siswa yang memiliki kemampuan interpersonal dalam kategori baik biasanya lebih menyenangi untuk berinteraksi dengan orang lain, tanpa batasan usia baik dengan mereka yang lebih tua atau lebih muda dan terkadang mereka sangat menonjol dalam kegiatan kerja kelompok, maupun kegiatan pembelajaran berbasis proyek (Campbell,2006: 172). Hal inilah yang mendukung terciptanya suasana pembelajaran yang penuh rasa kekeluargaan, bahkan siswa tidak segan untuk saling membantu dengan temannya yang termasuk kategori ABK.

\subsection{Faktor Penghambat Kegiatan Pembelajaran}

Selama pelaksanaan penelitian adapun faktor penghambat antara lain, fokus atau perhatian siswa yang cukup sulit, dikarenakan siswa masih disibukkan untuk melihat pekerjaan teman-teman disekitarnya. Ada beberapa siswa yang masih malu-malu untuk membaur atau bergabung bersama teman-temannya yang lain, sehingga proses interaksi menjadi kurang maksmial. Didalam kegiatan praktek, ada siswa yang tidak mau meminjamkan peralatannya kepada temannya yang lain sehingga guru atau peneliti harus memperhatikan jalannya praktek dilapangan dan menjadi penengah bagi mereka.

\section{Kesimpulan}

Berdasarkan deskripsi dari hasil penelitian dan pembahasan diatas, maka dapat ditarik kesimpulan, yaitu :

4.1 Implementasi Penggunaan Boneka Jari

Implementasi penggunaan boneka jari di SDN 027 Samarinda Utara pada siswa kelas II C menunjukkan adanya kecerdasan interpersonal yang baik, hal ini terlihat dari nampak adanyan kemampuan berhubungan dengan orang lain/bekerjasama serta mampu menengahi pertengkaran yang terjadi diantara mereka, baik didalam kelompoknya maupun di kelas tersebut.

4.2 Faktor-faktor pendukung pelaksanaan pembelajaran

Faktor pendukung yang ada dilapangan yaitu adanya sifat terbuka dari para siswa untuk dapat menerima pelajaran yang akan disampaikan sehingga proses sosialisasi pun berjalan dengan sangat baik.

\section{Daftar Pustaka}

[1] Amelia, L., \& Ramadhani, L. (2016). PENERAPAN METODE BERMAIN PERAN DALAM MENINGKATKAN KEMAMPUAN BERBICARA ANAK PADA KELOMPOK B DI TK BOHHATEMA ACEH BESAR. Jurnal Buah Hati, 3(2).

[2] Amelia, L., \& Ayu Marsella. (2018). MENINGKATKAN KEMAMPUAN INTERPERSONAL ANAK MELALUI METODE BERMAIN PERAN DENGAN MENGGUNAKAN BONEKA JARI PADA ANAK TK B2 DI PAUD SAVE THE KIDS BANDA ACEH. Jurnal Buah Hati, 5(2).

[3] Chatib, Munif. 2013. Sekolahnya Manusia: Sekolah Berbasis Multiple Intelligences di Indonesia. Bandung: Penerbit Kaifa.

[4] Chatib, Munif. 2012. Orangtuanya Manusia: Melejitkan Potensi dan Kecerdasan dengan Menghargai Fitrah Setiap Anak. Bandung: Penerbit Kaifa.

[5] E Mulyasa. (2013). Pengembangan dan Implementasi Kurikulum 2013. Bandung: Rosdakarya.

[6] Gardner, Howard. 2013. Multiple Intelligences, Kecerdasan Majemuk Teori dalam Praktik. Tangerang Selatan: Interaksara.

[7] Gordon, Huggins-Cooper. 2013. Meningkatkan 9 Kecerdasan Anak. Jakarta: PT Bhuana Ilmu Populer. 
[8] Santoso, B. (2010) . Skema dan Mekanisme Pelatihan: Panduan Penyelenggaraan Pelatihan. Jakarta: Yayasan Terumbu Karang Indonesia (TERANG).

[9] Sugiyono. 2015. Metode Penelitian Pendidikan, Pendekatan Kuantitatif, Kualitatif, dan R \& D. Bandung: Alfabeta. 